\title{
STRATEGI PENGEMBANGAN WISATA NON-BAHARI DI KAWASAN WAHA, PULAU TOMIA, KABUPATEN WAKATOBI
}

\author{
Fitrawan Umar \\ Universitas Muhammadiyah Makassar \\ fitrawan.umar@gmail.com
}

\begin{abstract}
ABSTRAK
Pariwisata menjadi sektor unggulan di Kabupaten Wakatobi, Provinsi Sulawesi Tenggara. Objek wisata yang terkenal di Wakatobi berkaitan erat dengan sektor bahari, terutama aktivitas penyelaman (diving). Guna meningkatkan kualitas kepariwisataan di masa mendatang, diperlukan variasi produk wisata selain bahari di Wakatobi. Penelitian ini menggunakan metode observasi, wawancara, dan focus group discussion (FGD). Datadata penelitian dianalisis melalui SWOT untuk menghasilkan strategi pengembangan. Hasil penelitian menunjukkan beberapa objek potensial pariwisata non-bahari, seperti puncak perbukitan Waha, mata air Patuha, Benteng Patuha, dan Pesta Adat Safara. Strategi pengembangan yang diusulkan di antaranya ialah perencanaan fisik kawasan, peningkatan infrastruktur, sarana dan prasarana, serta peningkatan kapasitas sumber daya manusia.
\end{abstract}

Kata kunci: Non-Bahari, Pariwisata, Wakatobi.

\section{PENDAHULUAN}

Sektor pariwisata dunia dari tahun ke tahun menunjukkan perkembangan yang pesat. Pariwisata menjadi salah satu faktor pertumbuhan ekonomi terbesar dan tercepat negara-negara di dunia. United Nation Word Tourism Organization (UNWTO) (2017) merilis bahwa $10 \%$ pendapatan dunia berasal dari pariwisata.

Data menunjukkan adanya peningkatan signifikan para wisatawan di dunia. Tahun 2010, wisatawan dunia tercatat sebanyak 674 juta orang. Tahun 2016, wisatawan dunia telah mencapai 1 milyar 200 juta orang. (UNWTO, 2017).

Di Indonesia, pariwisata telah menjadi salah satu sektor unggulan untuk meningkatkan devisa negara dan pendapatan daerah. Pariwisata juga berperan dalam membangkitkan perekonomian masyarakat suatu wilayah, menciptakan lapangan kerja baru, dan menjadi faktor pelestarian alam dan budaya suatu daerah (Kementerian Pariwisata, 2015). Nurmansyah (2014) menyebut bahwa pariwisata dapat meningkatkan investasi dan mendorong pembangunan, serta meningkatkan pendapatan pajak. Risman dkk (2016) menulis bahwa pariwisata dapat menjadi salah satu solusi alternatif untuk mengatasi kemiskinan.

Pemerintah Kabupaten Wakatobi sendiri sudah menempatkan pariwisata sebagai sumber utama pendapatan daerah. Jumlah kunjungan wisata diharapkan semakin meningkat agar pendapatan daerah turut meningkat.

Kabupaten Wakatobi memiliki potensi kepariwisataan dengan citra yang kuat, di antaranya karena: 1) Wakatobi sebagai kawasan konservasi nasional, yaitu Taman Nasional Wakatobi; 2) Kepulauan Wakatobi dikenal sebagai pusat segitiga terumbu karang (the coral triangle) dunia yang terkenal memiliki keindahan alam bawah laut; 3) Taman Nasional Wakatobi diakui oleh UNESCO sebagai salah satu cagar biosfer di dunia (Dinas Pariwisata Wakatobi, 2017).

Tren kunjungan wisata ke Wakatobi setiap tahun mengalami peningkatan dengan rasio pertambahan rata-rata $15 \%$. Tahun 2015 , jumlah pengunjung wisata domestik mencapai 11.401 orang, sementara pengunjung mancanegara mencapai 6.626 orang (Badan Pusat Statistik, 2016). 
Tren kunjungan pariwisata Wakatobi perlu dipertahankan dan lebih ditingkatkan lagi. Dibanding dengan daerah wisata lain di Indonesia, Kabupaten Wakatobi masih tergolong tertinggal.

Usaha-usaha untuk mengembangkan pariwisata Wakatobi perlu dilakukan, di antaranya dengan variasi produk pariwisata. Penambahan variasi produk pariwisata Wakatobi dapat dilakukan melalui pengembangan sektor non-bahari.

Selama ini pariwisata Wakatobi bertumpu pada produk wisata bahari. Wakatobi masih memiliki potensi lain, berupa keunikan alam, budaya, dan sejarah yang kuat.

Pengembangan wisata non-bahari diharapkan dapat menambah jumlah dan durasi kunjungan wisata di Wakatobi. Pariwisata bahari dan non-bahari akan saling menunjang di masa mendatang.

Sebagai kasus, Pulau Tomia adalah salah satu pulau utama favorit di Wakatobi. Perairan di sekitar pulau ini menjadi tujuan wisata spot penyelaman yang telah dikenal sampai mancanegara. Namun, sektor non-bahari di Pulau Tomia belum berkembang. Wisatawan tidak punya objek tujuan wisata selain menikmati spot diving.

\section{METODE}

Metode yang dilakukan dalam penelitian ini adalah observasi, wawancara, dan focus group discussion (FGD). Observasi dilakukan untuk mengidentifikasi objek yang berpotensi menjadi tujuan wisata, dan wawancara dilakukan kepada Kepala Dinas Pariwisata Kabupaten Wakatobi. Adapun FGD melibatkan unsur satuan kerja pemerintah daerah (SKPD) yang berkepentingan di sektor pariwisata, kepala-kepala desa, tokoh masyarakat, dan lembaga-lembaga kemasyarakatan.

Penelitian ini menggunakan analisis
SWOT dalam penentuan strategi pengembangan pariwisata. Penelitian serupa pernah dilakukan Flamin dan Asnaryati (2013), serta Nasution dkk (2015).

\section{HASIL DAN PEMBAHASAN Hasil Penelitian}

\section{Gambaran Umum Kawasan Waha, Pulau Tomia}

Kawasan Waha terletak di ujung sebelah utara Pulau Tomia, yang secara administrasi termasuk dalam Kecamatan Tomia, Kabupaten Wakatobi, Sulawesi Tenggara. Kawasan Waha adalah pintu masuk di Pulau Tomia. Di kawasan ini terdapat dermaga yang menghubungkan Pulau Tomia dengan sekitarnya. Pulau Tomia sendiri merupakan pulau utama ketiga di Kabupaten Wakatobi.

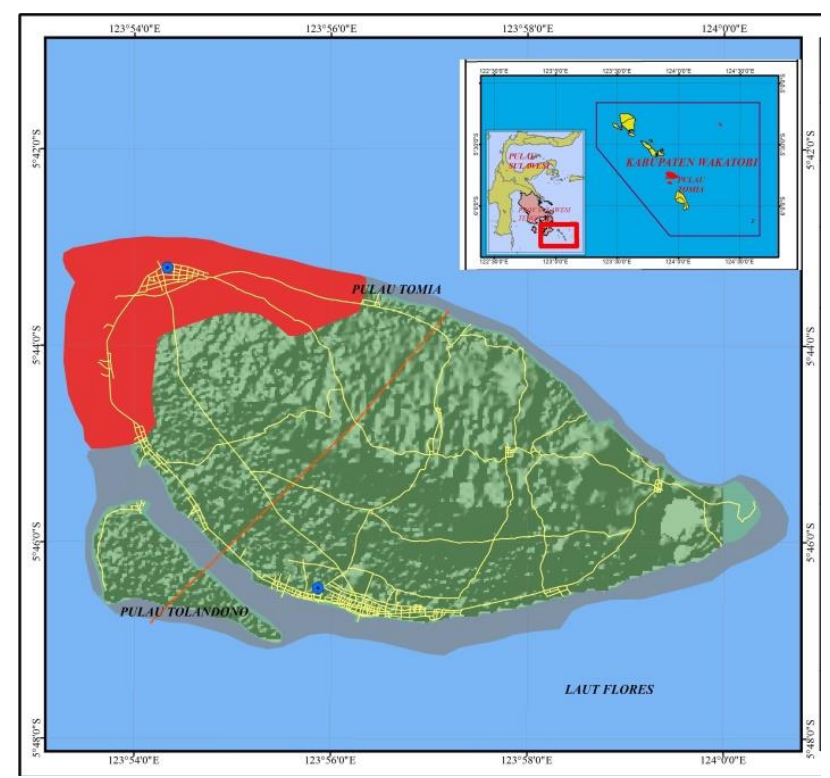

Sumber: Olahan Peta RIPPARDA Wakatobi, 2017

Gambar 1 Peta Administrasi Waha, Pulau Tomia

Perairan Waha terkenal sebagai spot diving dengan pemandangan laut yang indah. Keanekaragaman hayati seperti terumbu karang dan ikan-ikan berwarna-warni menjadi daya tarik utama para wisatawan berkunjung ke kawasan ini. Beberapa spot yang ramai dikunjungi di antaranya ialah Mari Mabok, Ali Reef, Dunia Baru, Roma, House Reef, Teluk Maya, dan lain-lain.

Pola pemanfaatan lahan di Kawasan Waha didominasi oleh lahan belum terbangun. Persentase lahan belum terbangun di Kawasan Waha mencapai $82,2 \%$ atau seluas 238 ha, sedangkan lahan terbangun hanya $17,9 \%$ atau seluas 45,3 ha. Pemanfaatan lahan terbangun sebagian besar berlokasi di wilayah pesisir dengan peruntukan sebagai permukiman dan perdagangan atau jasa. 


\section{Aksesibilitas Kawasan}

Kawasan Waha dapat diakses melalui jalur laut dari Pulau Wangi-Wangi yang merupakan pintu masuk Wakatobi. Akses dari luar kabupaten menuju Pulau Wangi-Wangi dapat ditempuh lewat jalur udara melalui Bandar Udara Matahora. Di Pulau Tomia, khususnya di Kecamatan Tomia Timur, juga terdapat bandara, tetapi hanya berupa bandara khusus privat pariwisata yang dikelola oleh pihak swasta asing (Wakatobi Dive Resort).

Jalur laut menuju Kawasan Waha dapat diakses melalui Pelabuhan Waha. Pelabuhan ini merupakan pelabuhan penumpang yang melayani trayek regional dan lokal. Trayek regional melayani akses hingga Pelabuhan Nusantara Kendari, Ibukota Provinsi Sulawesi Tenggara. Trayek lokal melayani akses yang terhubung dengan pelabuhan pulau-pulau utama Wakatobi, yakni Pelabuhan Liya Onemelangka (Wangi-Wangi), Pelabuhan Ambeua (Kaledupa), Pelabuhan Buranga (Kaledupa), Pelabuhan Langge (Kaledupa Selatan), dan Pelabuhan Taou (Kaledupa Selatan).

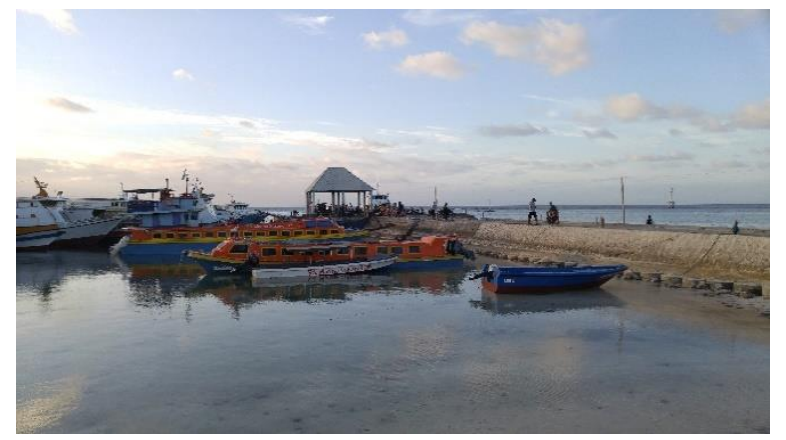

Sumber: Dok.pribadi, 2017

Gambar 2. Gambar Pelabuhan Waha

\section{Sarana Penunjang Pariwisata}

Fasilitas akomodasi di Kawasan Waha menunjukkan jumlah terbanyak di antara kelurahan/desa lain di Kecamatan Tomia. Terdapat setidaknya 3 penginapan dengan jumlah 25 kamar dan 43 tempat tidur, serta 1 resort dengan jumlah 28 kamar dan 36 tempat tidur. Jumlah tamu pengunjung pada tahun 2015 tercatat sebanyak 1.441 orang. Jumlah ini masih terhitung kecil dibandingkan potensi pariwisata di Pulau Tomia.

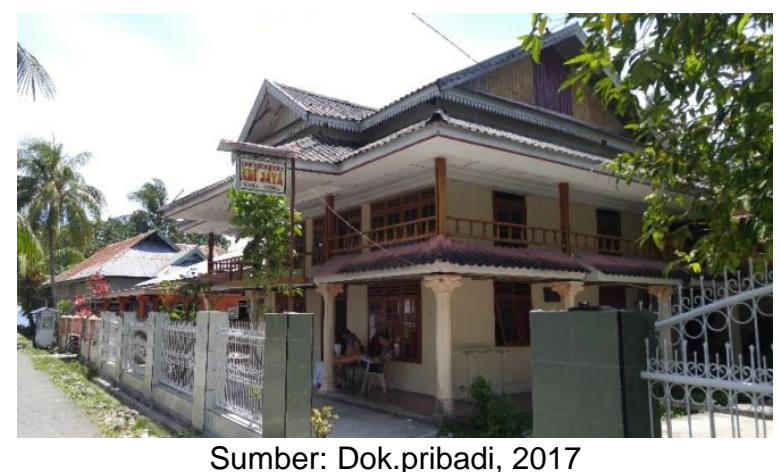

Gambar 3. Salah satu penginapan di Waha

Fasilitas lain ialah pusat informasi wisatawan di area Pelabuhan Waha. Hal ini menunjukkan komitmen pemerintah setempat untuk menyambut dan melayani wisatawan. Namun, pusat informasi ini kurang berfungsi dengan baik karena tidak didukung oleh prasarana yang memadai.

Ketersediaan fasilitas rumah makan atau kuliner di Kawasan Waha telah dilakukan oleh beberapa kelompok usaha masyarakat. Namun, kehadiran rumah makan ini belum banyak menarik para wisatawan. Potensi kuliner khas Wakatobi belum terangkat dengan baik.

Kawasan Waha juga memiliki sentra penjualan souvenir berupa kain tenun khas Wakatobi. Potensi usaha di bidang souvenir lain masih perlu dioptimalkan, seperti kaos, gantungan kunci, dan cenderamata yang lain.

\section{Prasarana Penunjang Pariwisata}

Jaringan jalan utama di Kawasan Waha umumnya berkondisi baik dengan material berupa perkerasan aspal dan lebar 4-8 meter. Jaringan jalan ini dilalui kendaraan dengan jumlah Ialu lintas harian relatif rendah setiap harinya.

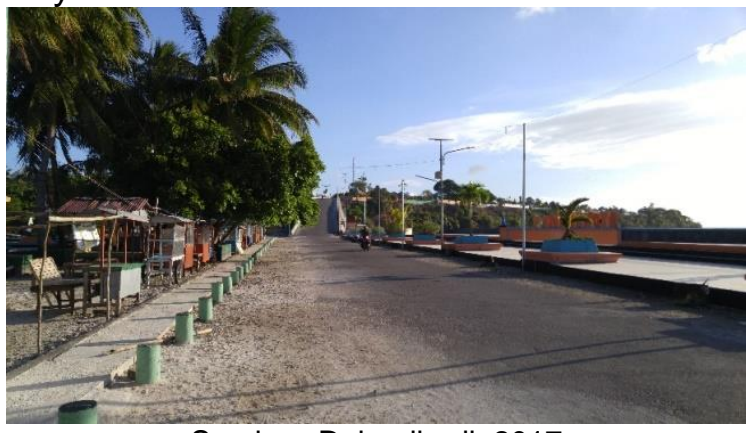

Sumber: Dok.pribadi, 2017

Gambar 4. Jaringan Jalan di Kawasan Waha. 
Namun, jaringan jalan menuju objek-objek wisata non bahari potensial masih belum memadai. Jaringan jalan tersebut masih berupa tanah hingga perkerasan.

Sistem transportasi angkutan umum tidak tersedia di Kawasan Waha. Wisatawan hanya mengandalkan jasa travel untuk menuju kawasan wisata spot-spot penyelaman.

Prasarana penunjang lain ialah air bersih. Air bersih sangat berpengaruh terhadap pelayanan kawasan wisata. Sumber air bersih utama di Kawasan Waha masih berupa sumur dan air tanah. Jaringan PDAM belum sepenuhnya melayani kawasan ini.

Selain itu, prasarana persampahan juga menunjang keberlanjutan kawasan wisata, yaitu untuk menjamin kebersihan lokasi destinasi wisata. Jaringan persampahan di Kawasan Waha, baik di kawasan wisata maupun di kawasan permukiman, belum tersistem dengan baik.

Adapun kondisi kelistrikan di Kawasan Waha secara umum sudah memadai lewat jaringan pelayanan PLN. Penggunaan energi listrik bertenaga surya pun mulai dikembangkan, di antaranya di beberapa ruas jalan Waha.

Kawasan Waha juga telah memiliki beberapa tower jaringan telekomunikasi. Namun, jaringan telekomunikasi yang melayani Kawasan Waha hanya satu provider, yakni Telkomsel.

\section{Pembahasan \\ Identifikasi Kawasan Wisata Non-Bahari}

Secara umum terdapat lima jenis pariwisata, yakni 1) pariwisata untuk menikmati perjalanan; 2) pariwisata untuk rekreasi; 3) pariwisata untuk kebudayaan; 4) pariwisata untuk olahraga; 5) pariwisata untuk konvensi.

Wisata bahari dapat dikategorikan sebagai pariwisata untuk rekreasi ataupun olahraga. Wisata bahari adalah wisata yang daya tariknya bersumber dari bentang laut atau pantai, dengan kegiatan berupa berenang, snorkeling, diving, surfing, berlayar, berjemur, memancing, dan lain-lain (Fandeli, 1995). Wisata non-bahari berarti wisata di luar kegiatan-kegiatan tersebut.
Berdasarkan analisis, terdapat beberapa jenis pariwisata non-bahari yang potensial untuk dikembangkan.

\section{Puncak Perbukitan}

Puncak perbukitan memiliki potensi pemandangan alam yang menarik. Dari atas puncak terlihat hamparan laut dengan gradasi warna yang menyatu dengan batas langit. Pada malam hari, area ini menyuguhkan pemandangan kerlip cahaya lampu kawasan perkotaan yang ada di bawah, serta kerlip bintang di atas langit.

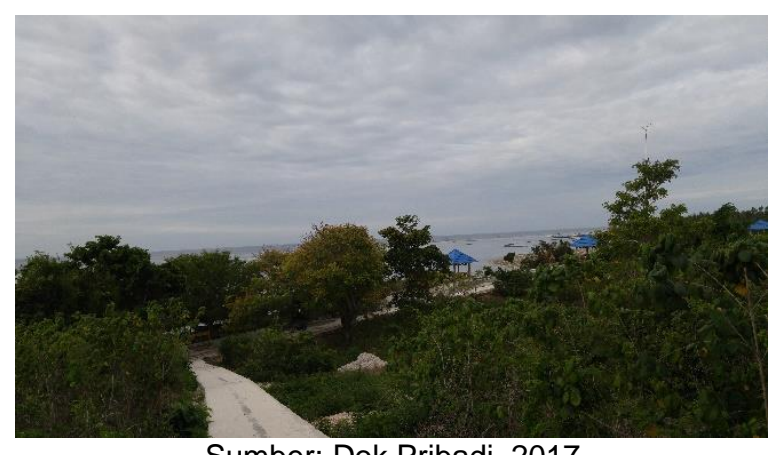

Sumber: Dok.Pribadi, 2017

Gambar 5. Area Puncak Perbukitan Waha

Lokasi perbukitan yang tak jauh dari perkotaan Waha membuat area ini mudah untuk dijangkau. Masyarakat Waha telah mengenal area ini dan memanfaatkannya sebagai tempat berkumpul atau wisata alternatif. Beberapa warga memanfaatkan lokasi untuk berjualan. Namun, di kalangan wisatawan, area ini tidak begitu dikenal sehingga hanya memiliki sedikit pengunjung.

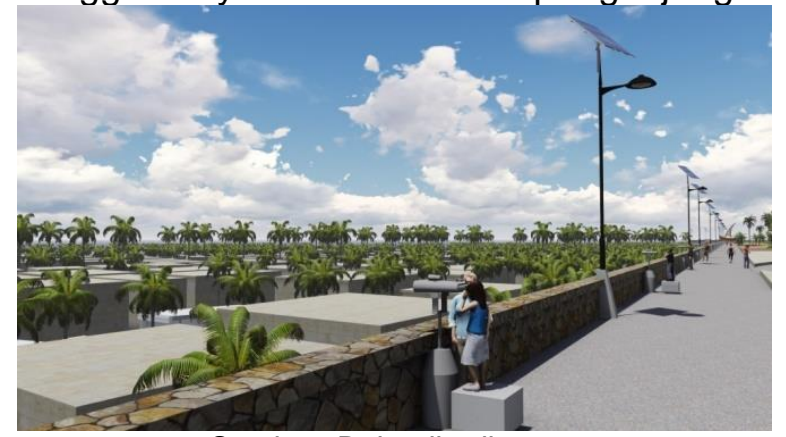

Sumber: Dok.pribadi, 2017

Gambar 6. Ilustrasi Perencanaan Perbukitan Waha

Perancangan wisata di lokasi perbukitan dapat dilakukan dengan pembangunan anjungan gardu pandang. Gardu pandang 
dapat berupa plaza tempat masyarakat untuk bersosialisasi. Fasilitas yang dapat disediakan adalah gazebo-gazebo dan teropong binokuler untuk melihat pemandangan di kejauhan.

2. Mata Air Patuha

Potensi wisata di area ini adalah mata air yang jernih dan suasana alam yang masih natural. Beberapa warga telah memanfaatkan mata air untuk permandian. Informasi mengenai lokasi ini sangat minim sehingga sangat jarang dikunjungi wisatawan luar.

Perancangan wisata Mata Air Patuha dapat dilakukan dengan konsep permandian umum. Pembangunan wisata dilakukan secara terbatas dengan mengutamakan kelestarian lingkungan. Beberapa fasilitas wisata dapat ditambahkan, seperti gazebo dan kamar ganti. Akses menuju mata air masih berupa jalan tanah sehingga memerlukan peningkatan kualitas jalan.

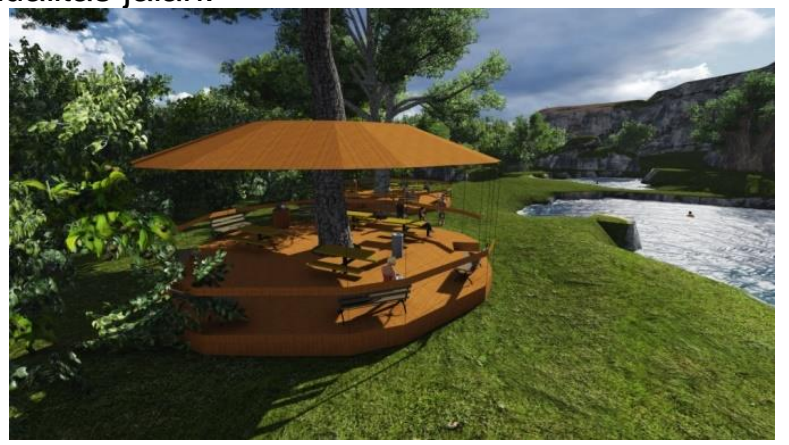

Sumber: Dok.pribadi, 2017

Gambar 7. Ilustrasi Perencanaan Permandian Mata Air Patuha

\section{Benteng Patuha}

Situs bekas benteng, yakni Benteng Patuha, memiliki kekayaan sejarah dan budaya yang dapat dikembangkan sebagai objek tujuan wisata. Benteng Patuha berada di kawasan perbukitan Desa Patuha II Kecamatan Tomia, dan diperkirakan berdiri pada abad ke-18. Dulunya kompleks benteng ini adalah pusat pertahanan kerajaan dan kawasan permukiman masyarakat. Lokasi benteng berada di atas tebing karang dan menjadi nilai tambah karena menyuguhkan pemandangan yang menarik dari ketinggian.

Benteng Patuha memiliki ciri khusus berupa tiga buah lawa atau gerbang. Selain itu, terdapat beberapa makam tua dan bekas bangunan masjid dari batu gunung dan batu kapur. Di kawasan Benteng Patuha juga terdapat jamban batu kuno, bekas meriam, dan ruang benteng yang masih tersisa.

Masyarakat sekitar memanfaatkan kompleks benteng untuk melakukan ritual adat. Masyarakat mendirikan baruga sebagai tempat perkumpulan dan menggelar pesta atau taritarian.

Perancangan wisata di kawasan Benteng Patuha dapat dilakukan dengan penambahan fasilitas penunjang pariwisata. Perancangan wisata harus mengutamakan kepentingan sejarah dan kebudayaan masyarakat.

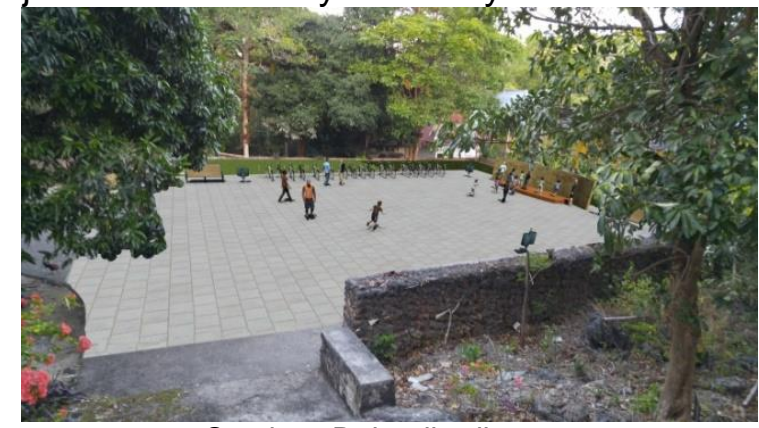

Sumber: Dok.pribadi, 2017

Gambar 8. Ilustrasi Perencanaan Kawasan Benteng Patuha

\section{Pesta Adat Safara}

Selain objek wisata alam potensial, Kawasan Waha juga memiliki hajatan budaya yang dapat menarik wisatawan, yakni Pesta Adat Safara. Pesta adat dilakukan pada bulan Safar menurut Kalender Hijriah (Islam) yang merupakan ungkapan syukur para nelayan/ pelaut kepada Tuhan atas hasil-hasil laut. Pesta adat Safara dimulai dengan membersihkan pantai secara bersama-sama, kemudian diakhiri dengan ritual Siri Wale, yakni mandi dan makan bersama-sama di laut.

Acara adat Safara sudah dimanfaatkan oleh pemerintah dan masyarakat setempat sebagai ajang promosi budaya lewat acara Festival Budaya Pulau Tomia. Acara festival diisi dengan berbagai atraksi seni, seperti taritarian, musik, dan pembuatan kue tradisional khas Wakatobi.

Pesta adat dan festival budaya ini dapat menjadi event pariwisata tahunan untuk mengangkat citra Kawasan Waha dan Pulau Tomia. Perancangan fisik dapat dilakukan 
dengan membenahi sarana tempat acara berangsung, yakni Lapangan Waha. Kondisi Lapangan Waha belum memadai untuk menunjang pelayanan pariwisata.

\section{Analisis SWOT}

1. Strength (kekuatan)

Faktor kekuatan Kawasan Waha di antaranya ialah: pertama, keunikan budaya dan sejarah masyarakat Waha, Pulau Tomia. Ragam budaya di Waha terdiri dari tari-tarian, kuliner lokal, kain tenun, dan tradisi-tradisi adat. Keunikan sejarah berupa situs-situs benteng peninggalan kerajaan yang pernah jaya di Waha.

Kedua, keindahan pemandangan alam. Meski berbentuk kepulauan, keindahan daratan Waha tak kalah dengan keindahan pantai dan bawah lautnya. Waha memiliki kawasan puncak perbukitan dan mata air alami di tengah-tengah hutan lokal.

Ketiga, promosi wisata Kawasan Waha telah tertuang dalam promosi wisata Wakatobi secara umum. Pemerintah Wakatobi sangat mengandalkan pemasukan dari sektor pariwisata sehingga aktivitas promosi giat dilakukan.

Keempat, kelembagaan pariwisata di Waha, baik dari pemerintah daerah, aparatur desa, dan lembaga-lembaga masyarakat, sangat mendukung kegiatan-kegiatan pariwisata. Mereka merasakan manfaat positif dari meningkatnya sektor pariwisata di daerahnya.

2. Weakness (kelemahan)

Faktor kelemahan Kawasan Waha di antaranya ialah: pertama, beberapa jaringan jalan menuju objek potensial masih berupa jalan tanah sehingga menyulitkan wisatawan untuk menjangkaunya.

Kedua, tidak ada angkutan umum darat sebagai sarana pergerakan internal destinasi pariwisata. Wisatawan hanya mengandalkan jasa perjalanan (travel).

Ketiga, pelayanan air bersih masih terbatas. Akses PDAM masih terbatas di Pulau Tomia.

Keempat, kapasitas sumber daya manusia (SDM) di bidang kepariwisataan masih minim. SDM yang dimaksud ialah seperti tenaga pemandu tersertifikasi, peneliti kepariwisataan, kemampuan bahasa asing masyarakat, dan pengelola atraksi wisata.

\section{Opportunity (peluang)}

Faktor peluang Kawasan Waha di antaranya ialah: pertama, jumlah kunjungan wisatawan menuju Wakatobi menunjukkan tren yang positif. Rasio pertambahan wisatawan rata-rata $15 \%$ setiap tahun. Tren ini juga berimbas pada peningkatan kunjungan ke Kawasan Waha, Pulau Tomia.

Kedua, Pulau Tomia telah dikenal sebagai salah satu lokasi penyelaman terbaik. Pulau ini menjadi destinasi favorit wisatawan yang datang ke Wakatobi. Sementara Kawasan Waha merupakan pintu masuk menuju Pulau Tomia.

Ketiga, wisata Wakatobi telah dipromosikan secara nasional hingga mancanegara. Pemerintah pusat turut aktif memperkenalkan pariwisata Wakatobi ke dunia internasional.

4. Threats (hambatan)

Faktor hambatan di Kawasan Waha di antaranya ialah: pertama, anggaran daerah Wakatobi masih terbatas untuk membiayai seluruh kebutuhan infrastruktur dan saranaprasarana pariwisata. Hal ini menyulitkan pengembangan pariwisata di Kabupaten Wakatobi, terkhusus untuk Kawasan Waha, Pulau Tomia.

Kedua, Pemerintah Wakatobi masih berfokus ke wisata bahari. Hal ini menyebabkan objek wisata lain tidak berkembang.

\section{Strategi Pengembangan Pariwisata Non- Bahari}

Perumusan strategi pengembangan pariwisata perlu memperhatikan komponen sistem dan unsur industri pariwisata. Leiper (1990) mengklasifikasikan sistem pariwisata sebagai berikut: 1) sektor pemasaran, seperti kantor biro perjalanan, kantor pemasaran maskapai, dan kantor promosi daerah tujuan; 2) sektor perhubungan, seperti penerbangan, bus, dan kereta api; 3) sektor akomodasi, seperti hotel dan penginapan; 4) sektor daya tarik/ atraksi wisata, seperti wisata alam, buatan, dan budaya; 5) sektor tour operator, seperti 
perusahaan penyelenggara dan penyedia paket wisata; 6) sektor pariwisata, seperti tokoh souvenir, asuransi perjalanan, dan bank; 7) sektor regulator, seperti pemerintah dan asosiasi di bidang pariwisata.

Perumusan strategi juga mempertimbangkan unsur keberlanjutan pariwisata. Edgel (2006) menyebut prinsip keberlanjutan pariwisata, yakni: 1) Memanfaatkan dan memelihara secara optimum sumberdaya lingkungan; 2) Menghargai keaslian nilai-nilai sosial budaya dari komunitas lokal; 3) Memberi manfaat sosial ekonomi dalam jangka panjang kepada semua pemangku kepentingan, seperti kesempatan kerja dan pengentasan kemiskinan.

Berdasarkan kajian teori dan analisis tersebut, disusun strategi sebagai berikut:

1. Strategi Strength-Opportunity (SO)

Di bidang peningkatan atraksi wisata, perencanaan fisik objek wisata alam non-bahari perlu dilakukan. Termasuk di dalamnya pembangunan sarana dan prasarana penunjang pariwisata.

Di bidang pemasaran pariwisata, promosi sektor non-bahari perlu ditingkatkan. Baik pada tingkat regional, maupun di tingkat internasional.

2. Strategi Weakness-Opportunity (WO)

Di bidang infrastruktur, perlu dilakukan peningkatan kualitas jalan, perluasan pelayanan air bersih, telekomunikasi, listrik, dan jaringan persampahan. Perancangan jalur sepeda dan angkutan umum seperti bis pariwisata dapat dilakukan.

Di bidang sumber daya manusia, pelatihan-pelatihan teknis untuk pengelola pariwisata dan masyarakat di sekitar lokasi wisata perlu rutin dilakukan.

3. Strategi Strength-Threats (ST)

Di bidang investasi, dapat dilakukan peningkatkan kerja sama investasi pengelolaan pariwisata yang menguntungkan dan berkeadilan. Kerja sama investasi dengan pihak asing di sebuah resort Pulau Tomia dapat dijadikan bahan pertimbangan.

$\mathrm{Di}$ bidang kelembagaan, pemerintah daerah perlu didorong untuk memperhatikan objek wisata selain bahari agar dapat meningkatkan perekonomian wilayah.

4. Strategi Weakness-Threats (WT)

Mendorong keterlibatan pemerintah pusat untuk membiayai infrastruktur pariwisata, terutama di sektor non bahari Kabupaten Wakatobi.

\section{SIMPULAN}

Kawasan Waha, Pulau Tomia, memiliki sejumlah potensi untuk dikembangkan sebagai kawasan pariwisata non-bahari, di antaranya puncak perbukitan Waha, mata air Patuha, Benteng Patuha, dan Pesta Adat Safara. Pengembangan pariwisata non-bahari dapat dilakukan melalui perencanaan fisik kawasan, peningkatan sarana dan prasarana, serta peningkatan kapasitas sumber daya manusia. 


\section{DAFTAR PUSTAKA}

Badan Pusat Statistik. 2017. Kabupaten Wakatobi dalam Angka tahun 2016.

Dinas Pariwisata Kabupaten Wakatobi. 2017. Rencana Induk Pembangunan Pariwisata Daerah Kabupaten Wakatobi.

Edgell, S. L. 2006. Managing Sustainable Tourism: A Legacy for the Future. Binghamton, NY: The Haworth Hospitality Press.

Fandeli, Chafid. 1995. Dasar-Dasar Manajemen Kepariwisataan Alam. Yogyakarta : Penerbit Liberty.

Flamin, Alamsyah dan Asnaryati. 2013. Potensi Ekowisata dan Strategi Pengembangan Tahura NipaNipa, Kota Kendari, Sulawesi Tenggara. Jurnal Penelitian Kehutanan Wallacea Vol. 2 No. 2, Juni 2013.

Kementerian Pariwisata Republik Indonesia. 2015. Rencana Strategis Pengembangan Destinasi dan Industri Pariwisata tahun 2015-2019.

Leiper, P. 1990. Tourism Management. RMIT, Collingwood, Victoria.

Nasution, R.A., Purwoko, A., Hartini, K.S. 2016. Analisis Potensi dan Strategi Pengembangan Wisata Alam Air Terjun Silimalima di Kabupaten Tapanuli Selatan. Jurnal Universitas Sumatera Utara.

Nurmansyah, Agung. 2014. Potensi Pariwisata dalam Perekonomian Indonesia. Jurnal Ekonomi Bisnis \& Kewirausahaan Vol. III, No. 1, Januari 2014.

Risman, A., Wibhawa, B., Fedryasyah, R. 2016. Kontribusi Pariwisata Terhadap Peningkatan Kesejahteraan Masyarakat Indonesia. Prosiding Penelitian dan Pengabdian Kepada Masyarakat Universitas Padjajaran Vol.3 No.1.

United Nation World Tourism Organization. 2017. UNWTO Tourism Highlights: 2017 Edition. 